\title{
Effects of limestone and organic fertilizer on cassava yield and on chemical and physical soil properties
}

\author{
Amarílis Beraldo Rós ${ }^{1 *}$ (D), Nobuyoshi Narita ${ }^{1}$, Andréia Cristina Silva Hirata ${ }^{1}$, José Eduardo Creste ${ }^{2}$
}

$10.1590 / 0034-737 X 202067010004$

\begin{abstract}
Cassava has a high yield potential that can be achieved with adequate liming and fertilization of the soil. The objective of this study was to evaluate the effect of organic fertilizer application, in association or not with liming, on yield and morphological characteristics of cassava roots and on chemical and physical properties of the soil. The experiment was arranged in the split plot design. The plots corresponded to limestone rates $\left(0\right.$ and $\left.2.5 \mathrm{tha}^{-1}\right)$ and the subplots to chicken manure rates $\left(0,4,8\right.$, and $\left.12 \mathrm{t} \mathrm{ha}^{-1}\right)$. Yield showed no response to limestone application, but responded to manure, producing $43 \mathrm{t} \mathrm{ha}^{-1}$ of roots at the rate of $8 \mathrm{t} \mathrm{ha}^{-1}$. The treatments had no influence on soil density and total porosity. The addition of manure increased the concentrations of $\mathrm{P}$ and $\mathrm{K}$, while the addition of limestone increased $\mathrm{Ca}$ and $\mathrm{Mg}$ in the soil. The $\mathrm{pH}$ was affected only by limestone. Therefore, limestone does not affect crop yield and soil physical properties up to the amount used. Use of chicken manure up to $8 \mathrm{tha}^{-1}$ increased yield. Limestone and manure affect soil fertility in different ways.
\end{abstract}

Keywords: Manihot esculenta Crantz; chicken manure; root length; soil density; nutrient.

\section{INTRODUCTION}

Cassava (Manihot esculenta Crantz) crop has great importance in the tropics because it is a readily available food, easy to grow, with high capacity of transformation, and can be stored as food for several years (Nassar et al., 2009). It is a species native to Brazil (Valle, 2005) and is cultivated in all states of the country (IBGE, 2017). Its roots rank fifth among the world's most produced food behind only rice, wheat, potatoes, and corn (International Potato Center, 2010).

Due to its high yields, the crop extracts a large quantity of nutrients from the soil (Ternes, 2002), thus, the adequate amounts of nutrients is essential for cassava to express its yield potential.

The response of cassava to fertilization varies according to the soil fertility. The crop responds well to fertilization when cultivated on low fertility soils, while it may not present increase in yield with the application of fertilizers to an already medium to high fertility soil (Lorenzi, 2003).

Acidity or alkalinity of soils are the factors that most affect nutrient availability to plants (Caires, 2013). Therefore, the determination of the soil acidity and its amendment through liming allows greater nutrient utilization from fertilizer applications by cultivated plants.

Mineral or organic fertilizers can be used to amend soils, and the latter has greater advantages, with large beneficial effects on the chemical, physical, and biological properties of the soil (Ourives et al., 2010).

Odedina et al. (2011) compared cassava root yield between manure sources and NPK fertilizer and found that the use of poultry manure resulted in $44 \%$ and $29 \%$

\footnotetext{
Submitted on June $18^{\text {th }}, 2019$ and accepted on December $18^{\text {th }}, 2019$

Agência Paulista de Tecnologia dos Agronegócios, Polo Regional Alta Sorocabana, Presidente Prudente, São Paulo, Brazil. amarilis@apta.sp.gov.br; narita@apta.sp.gov.br; andreiacs@apta.sp.gov.br

${ }^{2}$ Universidade do Oeste Paulista, Presidente Prudente, São Paulo, Brazil. jcreste@ unoeste.br

* Corresponding author: amarilis@ apta.sp.gov.br
} 
increase of yield over the control without any source of fertilizer and over the treatment with NPK, respectively.

Mathias \& Kabambe (2015) studied the effects of cattle manure rates on cassava yield and found $26 \%$ increase in yield at the rate of $5 \mathrm{t} \mathrm{ha}^{-1}$ compared with the nonapplication of manure.

In sweet-potato, Rós et al. (2014) studied the effect on yield of chicken manure applied to the soil up to $12 \mathrm{t} \mathrm{ha}^{-1}$ and obtained a higher yield of tuberous roots $\left(23.6 \mathrm{t} \mathrm{ha}^{-1}\right)$ with the rate of $5.8 \mathrm{tha}^{-1}$ manure. It is of note that the use of manure at this rate resulted in $32 \%$ increase of yield, which can be explained by the physical and chemical improvements in the soil.

The increase in crop yield with application of manure to the soil is often related to improvements in soil chemical (Odedina et al., 2011) and physical properties (Mecabô Junior, 2013). The addition of organic fertilizers can raise the $\mathrm{pH}$, with consequent increase in cation exchange capacity and nutrient release (Menezes \& Silva, 2008, Pires et al., 2008). The manures are sources of $\mathrm{Ca}, \mathrm{Mg}, \mathrm{S}$, and micronutrients, as well as important nutrients for soil fertility maintenance (Odedina et al., 2011).

The benefits to soil physics by the application of manure include increased macroporosity, reduced soil density, and maintenance of aggregate stability (Mecabô Júnior, 2013). The organic matter favors increased total porosity and reduced soil penetration resistance (Magalhães, 2017)

Silva et al. (2012) argued that the application of cattle manure to the soil supplies and makes nutrient available to yam plants, improves the soil cation exchange capacity, and hence increases crop yield. Alves et al. (2008) pointed out that these effects are stronger in low CEC soils.

Considering the hypothesis that the application of limestone and organic fertilizer favors cassava crop yield and improves physical and chemical properties of the soil, the objective of this study was to evaluate the effect of the organic fertilizer (laying hen manure), in association or not with liming, on the yield and morphological characteristics of cassava roots and on chemical and physical properties of the soil.

\section{MATERIALAND METHODS}

The study was carried out in the municipality of Presidente Prudente, São Paulo, located at $22^{\circ} 11^{\prime}$ S latitude and $51^{\circ} 23^{\prime} \mathrm{W}$ longitude, and $424.29 \mathrm{~m}$ altitude. The experiment was conducted in a transition area between two soil types, Neosol and Argisol. The chemical analysis of the soil was performed before the land preparation for the experiment setup and resulted in: $\mathrm{pH}\left(\mathrm{CaCl}_{2}\right)=4.8$; organic matter $=11.1 \mathrm{~g} \mathrm{dm}^{-3} ; \mathrm{P}($ resin $)=4.8 \mathrm{mg} \mathrm{dm}^{-3} ; \mathrm{K}=$ $2.3 \mathrm{mmol}_{\mathrm{c}} \mathrm{dm}^{-3} ; \mathrm{H}+\mathrm{Al}^{+3}=23.8 \mathrm{mmol}_{\mathrm{c}} \mathrm{dm}^{-3} ; \mathrm{Ca}^{+2}=14.3$ $\mathrm{mmol}_{\mathrm{c}} \mathrm{dm}^{-3} ; \mathrm{Mg}^{+2}=4.5 \mathrm{mmol}_{\mathrm{c}} \mathrm{dm}^{-3} ; \mathrm{CEC}=44.9 \mathrm{mmol}_{\mathrm{c}} \mathrm{dm}^{-3}$; and $\mathrm{V} \%=47 \%$.

The experiment was arranged in a split-plot design, with eight replications. The plots consisted of two limestone rates ( 0 and $\left.2.5 \mathrm{t} \mathrm{ha}^{-1}\right)$ and the subplots consisted of 4 chicken manure rates $\left(0,4,8\right.$, and $\left.12 \mathrm{tha}^{-1}\right)$. Limestone characteristics were: $\mathrm{CaO}=36 \% ; \mathrm{MgO}=12 \%$, $\mathrm{NP}=94.2 ; \mathrm{RTNP}=85 \%$. Chicken manure was stored under plastic cover in an aerated area for 90 days prior to use. Manure chemical composition was as follows: $\mathrm{N}-2.21 \%$, $\mathrm{P}_{2} \mathrm{O}_{5}-7.9 \%, \mathrm{~K}_{2} \mathrm{O}-3.5 \%, \mathrm{Ca}-13.6 \%, \mathrm{Mg}-0.8 \%, \mathrm{~S}-$ $0.5 \%, \mathrm{MO}-33.3 \%$ and $\mathrm{C}-18.38 \%$.

Limestone was broadcast on plowed soil and incorporated with leveling disk harrow, 40 days before the cassava planting. Manure was broadcast and incorporated with a new plowing and, finally, land leveling was carried out with a leveling disk harrow, 10 days before planting.

Stem cuttings about $0.2 \mathrm{~m}$ in length taken from the middle third of plant stems of the cassava cultivar IAC 576-70, 12 months of age were planted at $0.1 \mathrm{~m}$ depth.

Each experimental plot comprised an area of $28.8 \mathrm{~m}^{2}$, with four rows and 10 plants each spaced $0.9 \mathrm{~m}$ between plants and $0.8 \mathrm{~m}$ between rows. The net plot consisted of the middle two rows in each plot, not using the plants at the ends of the rows. Cultural operations in the experimental area included manual weeding during the whole cycle of the crop.

Planting was carried out on 05/15/2015 and harvest was carried out 330 days after planting. Total yield (roots with diameter $\geq 0.03 \mathrm{~m}$ and length $\geq 0.10 \mathrm{~m}$ ) and commercial yield (roots with diameter $\geq 0.05 \mathrm{~m}$ and length $\geq 0.15 \mathrm{~m}$ ) were evaluated. Fresh mass, root length, and diameter of each root were also measured.

Soil samples were taken from the plots at $0-0.20 \mathrm{~m}$ depth to evaluate the chemical properties at harvest (11 months after planting) and samples with undisturbed structure (1 per plot) were collected from the middle portion of the 0 $0.30 \mathrm{~m}$ depth to evaluate soil physical properties of the soil eight months after planting. Soil properties evaluated were: active acidity $(\mathrm{pH})$, organic matter $(\mathrm{OM})$, phosphorus $(\mathrm{P})$, calcium $(\mathrm{Ca})$, magnesium $(\mathrm{Mg})$, potassium $(\mathrm{K})$, base sum (BS); cation exchange capacity (CEC); soil density (SD) and total porosity (TP).

The following methods of analyses were used: $\mathrm{pH}$ in $\mathrm{CaCl}_{2} ; \mathrm{P}, \mathrm{Ca}, \mathrm{Mg}$, and $\mathrm{K}$ by ion exchange resin, and organic matter by oxidation, according to Camargo et al. (2009). CEC and BS were calculated. SD was determined by the volumetric ring method, in which the soil sample mass dried at $105{ }^{\circ} \mathrm{C}$ is related to the sum of the volumes occupied by the particles and the pores, while TP was determined by the ratio between soil density (SD) and particle density (PD). Particle density (PD) is calculated 
by the volumetric flask method. Physical attributes were determined according to Embrapa (1997).

Results were analyzed by analysis of variance and means were compared by the Tukey test at $5 \%$ of probability or adjusted to polynomial regression equations. The model was selected based on the significance of the F test and the highest values of the coefficient of determination $\left(\mathrm{R}^{2}\right)$. The statistical significance was tested at $5 \%$ probability of error.

\section{RESULTS AND DISCUSSION}

No interaction was found between limestone application and chicken manure rates for any of the soil evaluated properties.

There was no difference between the treatments with and without limestone, and the results for total yield, commercial yield, length, diameter, and individual fresh root mass were $39.9 \mathrm{tha}^{-1}, 35.6 \mathrm{tha}^{-1}, 24.8 \mathrm{~cm}, 4.8 \mathrm{~cm}$, and 410.4 g, respectively. Otsudo \& Lorenzi (2004) and Souza et al. (2009) point out that the use of limestone has not promoted significant increases in cassava yield due to the tolerance of the crop to soil acidity. However, increased crop yield was reported by Campos et al. (2004) as being probably due to the higher acidity and lower fertility of the soil used in their study.

Total and commercial yields showed an estimated quadratic response to application of manure, with maximum points close to $8 \mathrm{tha}^{-1}$ of the fertilizer. The total and commercial yields obtained at this rate were 45 and $43 \mathrm{t} \mathrm{ha}^{-1}$, respectively (Figure 1). Amanullah et al. (2006) also reported increase in yield of cassava roots with application of poultry manure $\left(10 \mathrm{tha}^{-1}\right)$ and attributed the yield gain to improvements in soil physical properties and slow and constant availability of nutrients during the crop growing season. According to Amanullah et al. (2007), application of poultry manure to cassava provides good biomass production and better nutrient absorption, resulting in higher yield of tuberous roots.

The estimated yield quadratic response was also reported for other crops. Rós et al. (2014) reported that sweet potato fertilized with chicken manure up to the rate of $12 \mathrm{t} \mathrm{ha}^{-1}$ presented maximum commercial yield of tuberous roots $\left(23.6 \mathrm{t} \mathrm{ha}^{-1}\right)$ at the rate of $5.8 \mathrm{t} \mathrm{ha}^{-1}$, with decrease in yield at higher rates of manure. Oliveira et al. (2001) verified that the addition of chicken manure to yam crop promoted yield increase up to the rate of $6.6 \mathrm{t} \mathrm{ha}^{-1}$ and yield reduction at higher rates. Therefore, the use of excessive amounts of organic fertilizers results in a decrease of crop yield. Primavesi (2002) argued that excess NPK reduces nutrient absorption and can reach toxic levels, causing imbalance in the absorbed and metabolized macro and micronutrient concentrations, which results in yields lower than the plant potential when there is a balance between the rates of absorption and metabolization.

However, Rós et al. (2014) studying the same cassava variety as the present study, found that the rates up to 18 t ha $\mathrm{a}^{-1}$ did not reduce yield, which indicates that for the those environmental conditions the amount of manure was not capable of damaging the crop.

Length and root mean diameter showed linear behavior. However, with increasing manure rates, the length decreased from $26.8 \mathrm{~cm}$ at the rate 0 to $22.7 \mathrm{~cm}$ at the rate $12 \mathrm{t} \mathrm{ha}^{-1}$ (Figure 2A), while the diameter increased from $4.7 \mathrm{~cm}$ at the rate 0 to $4.9 \mathrm{~cm}$ at the rate $12 \mathrm{t} \mathrm{ha}^{-1}$ (Figure 2B). The fresh root mass showed no change, with mean value of $410.4 \mathrm{~g}$.

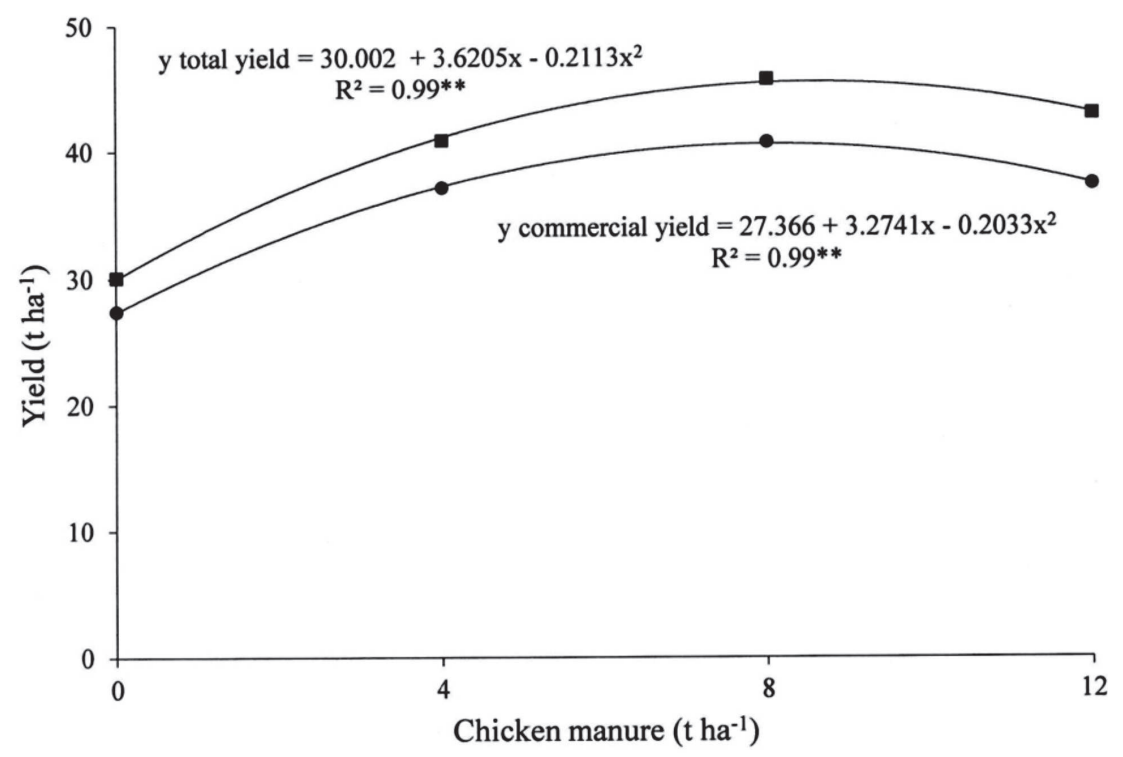

Figure 1: Total and commercial yields of cassava roots. ** Significant at $1 \%$ by test $\mathrm{F}$. 
The yield increase of cassava roots reported by Rós et al. (2014) occurred due to the increase in the number of roots per unit of plant, without any difference in individual mean fresh mass of roots. Thus, it is likely that, in the present work, the addition of manure to the soil, up to the rate of $8 \mathrm{t} \mathrm{ha}^{-1}$, also resulted in an increase in the number of roots with similar mean fresh mass per plant unit.

No interaction was found between limestone treatments and manure application rates as well as application of limestone and manure caused no change in soil density $\left(1.57 \mathrm{Mg} \mathrm{m}^{-3}\right)$ and total soil porosity $\left(0.4 \mathrm{~m}^{3}\right.$ $\mathrm{m}^{-3}$ ). Rós et al. (2014) found that application of manure up to the rate of $18 \mathrm{t} \mathrm{ha}^{-1}$ to a Argisol, sandy texture, reduced soil density and increased porosity. The difference from this study may be attributed to the type of soil and the rate used, since it is expected that reduction in soil density would occur only with the continuous application of manure (Arriaga \& Lowery, 2003). Dortzbach (2009) studied the influence of pig slurry, deep-litter, and urea on physical attributes of an Argisol, and even with the continuous application over five years, they found no changes in soil density, total porosity, macroporosity, microporosity, and water retention.

No interaction was found between limestone treatments and manure application for any of the soil chemistry characteristics studied.
There was no change in the soil $\mathrm{pH}$ at harvest as a result of manure application. This is because the $\mathrm{pH}$ usually increases when there is a continuous application of organic fertilizer (Mitchell \& Tu 2006; Galvão et al. 2008). However, the $\mathrm{pH}$ varied as a function of the application ( $\mathrm{pH}=5.46)$ or not $(\mathrm{pH}=4.86)$ of limestone, and, as expected, the application of limestone raised the pH of the soil. Dos Anjos et al. (2011) also confirmed the increase in soil $\mathrm{pH}$, even when it was measured at 27 months after the limestone application.

The organic matter concentration showed no change in function of application of limestone and manure, with a mean of $11.83 \mathrm{~g} \mathrm{dm}^{-3}$. This result differed from reports by Rós et al. (2014), in which the application of chicken manure resulted in increased organic matter in the soil. This difference is probably related to the amount of manure used (up to $18 \mathrm{t} \mathrm{ha}^{-1}$ ).

Phosphorus and potassium were not influenced by limestone application, but their concentrations increased with increase in the rate of manure used. These results indicate that these nutrients were supplemented by manure at rates higher than the plant requirements, resulting in significant increases in their concentrations. P concentration presented an adjusted response according to the linear model, showing increase in the concentration with the increase in manure rate (Figure $3 \mathrm{~A})$. At the rate 0 ,

A

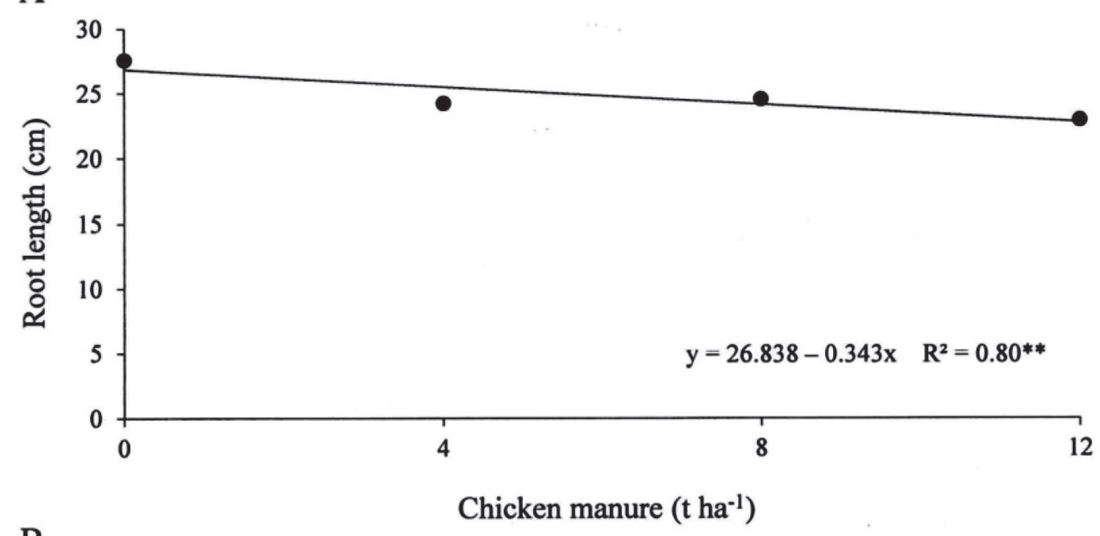

B

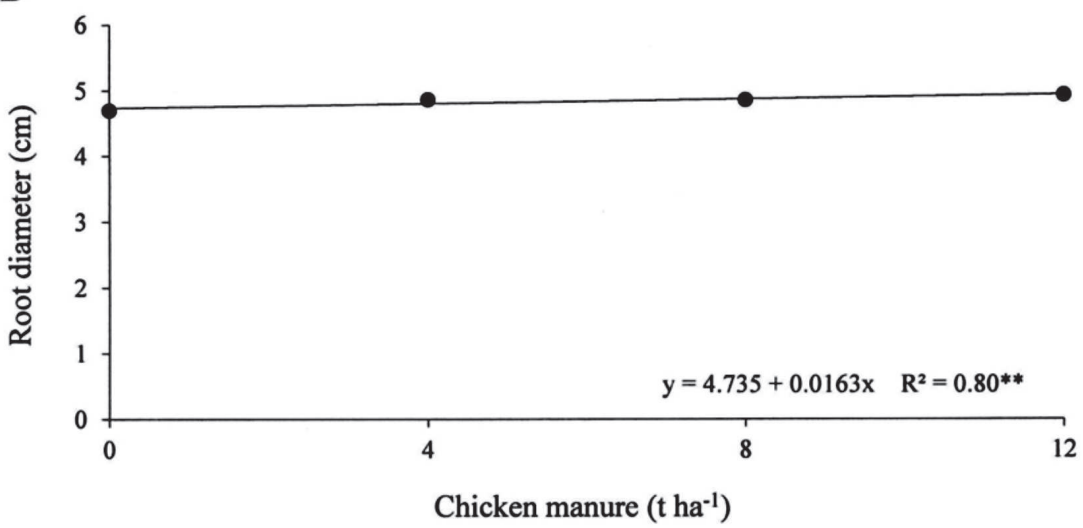

Figure 2: Length (A) and mean diameter (B) of roots. ** Significant at $1 \%$ by test $\mathrm{F}$. 
the estimated mean was approximately $5.55 \mathrm{mg} \mathrm{dm}^{-3}$ and reached about $18.37 \mathrm{mg} \mathrm{dm}^{-3}$ with the application of $12 \mathrm{t}$ ha $^{-1}$ of manure, resulting in a $230 \%$ increase. Rós et al. (2014), working with sweet potato, also used chicken manure up to $12 \mathrm{t} \mathrm{ha}^{-1}$, but the soil $\mathrm{P}$ concentration increased in $1313 \%$, which is related to soil and crop conditions of their study. Reduction in $\mathrm{P}$ adsorption in the soil is due to the carboxylic and phenolic functional groups present in the organic matter responsible for blocking the positive charge sites of $\mathrm{Fe}$ and $\mathrm{Al}$ oxides, which are $\mathrm{P}$ adsorption sites (Hue, 1991). Silva \& Menezes (2007) found that cattle manure applied to cassava crop increased extractable $\mathrm{P}$ in the soil. Moreover, in the case of cassava, there is a significant response to $\mathrm{P}$ application, as Brazilian soils are generally low in its concentration (Mattos et al., 2002; Pereira et al., 2012).

Potassium is the nutrient absorbed in greater amounts by cassava (Otsubo \& Lorenzi, 2004), it is, thus, essential for the crop to show high productivity. The K concentration also presented an adjusted response according to the linear model, showing increase in its concentration with the increase in manure rate (Figure $3 \mathrm{~B})$. At the rate 0 , the estimated mean was approximately $2.23 \mathrm{mmol} \mathrm{dm}^{-3}$ and the application of the highest rate increased to about $3.00 \mathrm{mmol}_{\mathrm{c}} \mathrm{dm}^{-3}$, resulting in a $35 \%$ increase. At harvest, the $\mathrm{K}$ concentration was higher than the concentration at planting, therefore, although the crop absorbed a great quantity of this nutrient, the manure provided $\mathrm{K}$ concentrations higher than the necessary to the crop. In their work with cassava, Rós et al. (2014) found that the application of up to $18 \mathrm{t} \mathrm{ha}^{-1}$ did not raise nutrient concentration in the soil at the time of harvest, which may be related to the pre-existing $\mathrm{K}$ concentration in the soil ( $\left.3.1 \mathrm{mmol}_{\mathrm{c}} \mathrm{dm}^{-3}\right)$.

Calcium and magnesium concentrations were not influenced by manure, but increased with limestone application (Table 1), that is, the amounts added of these nutrients to the soil by manure and that became available to the plants were used by the cassava crop. On the other hand, supply of calcium and magnesium by liming is common practice to raise the concentrations of these macronutrients in the soil, as the acidity correctives have $\mathrm{Ca}$ and $\mathrm{Mg}$ in their composition.

Increasing $\mathrm{Ca}$ and $\mathrm{Mg}$ concentrations with limestone application also increased the Base Sum (BS) (Table 1). Cation exchange capacity (CEC) was not significantly influenced by the application of limestone or manure, with mean value of $45.1 \mathrm{mmol}_{\mathrm{c}} \mathrm{dm}^{-3}$. This result differs from Alleoni et al. (2005) and Bambolim et al. (2015) who reported that the application of limestone increased CEC. However, by holding the CEC value and increasing the BS, the Base Saturation (V) increased with the limestone application (Table 1). Dos Anjos et al. (2011) also found that Base Saturation measured at 12 months after the

A

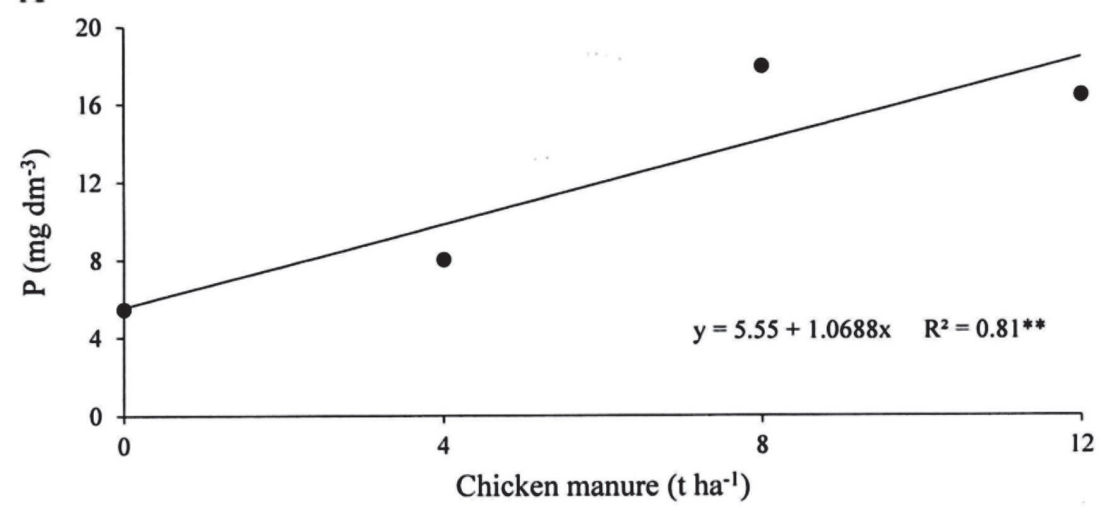

B

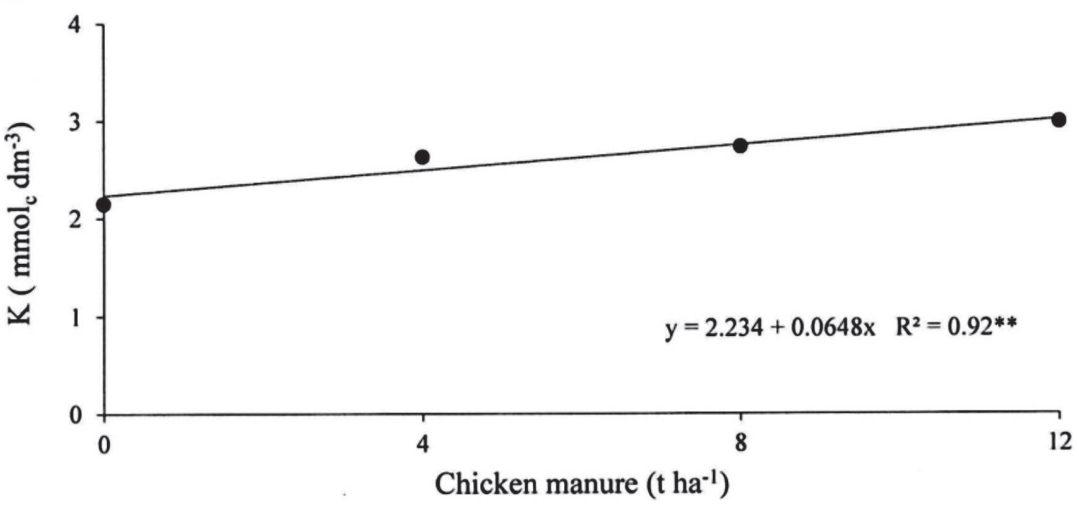

Figure 3: $\mathrm{P}(\mathrm{A})$ and $\mathrm{K}(\mathrm{B})$ concentrations in soil. ** Significant at $1 \%$ by test $\mathrm{F}$. 
Table 1: Calcium and magnesium concentrations, Base Sum (BS), and Base Saturation (V) as a function of limestone application to the soil

\begin{tabular}{|c|c|c|c|c|}
\hline \multirow{2}{*}{ Treatment } & $\mathrm{Ca}$ & Mg & BS & $\mathbf{V}$ \\
\hline & \multicolumn{3}{|c|}{$\mathrm{mmol}_{\mathrm{c}} \mathrm{dm}^{-3}$} & $\%$ \\
\hline With lime & $21.9 \mathrm{~A}$ & $6.0 \mathrm{~A}$ & $30.4 \mathrm{~A}$ & $64.9 \mathrm{~A}$ \\
\hline Without lime & $15.3 \mathrm{~B}$ & $4.3 \mathrm{~B}$ & $22.3 \mathrm{~B}$ & $50.8 \mathrm{~B}$ \\
\hline $\mathrm{CV}(\%)$ & 14.98 & 10.25 & 14.68 & 9.09 \\
\hline
\end{tabular}

Means followed by the same letter in the column are not significantly different by the Tukey test at $5 \%$ probability.

application of limestone in an orange orchard was higher than the control without limestone application. It is of note that Base Saturation, according to Natale et al. (2007), reflects in general the benefits of liming such as increase of $\mathrm{pH}, \mathrm{Ca}^{2+}, \mathrm{Mg}^{2+}$, and Base Sum and decrease of $\mathrm{Al}^{3+}$ and $\mathrm{H}+\mathrm{Al}$.

\section{CONCLUSIONS}

Under the conditions of the present study, the cassava crop showed no response to limestone application, maintaining yield and root characteristics independent of the application of the acidity corrective.

The crop responded to soil fertilization, increasing total and commercial yields with application of chicken manure up to the rate of about $8 \mathrm{tha}^{-1}$. The use of manure promoted changes in length and diameter of tuberous roots.

No difference was found in the physical properties soil density and total porosity due to the application of limestone and manure to the soil. Chicken manure application increased $\mathrm{P}$ and $\mathrm{K}$ concentrations, while limestone application increased $\mathrm{Ca}$ and $\mathrm{Mg}$ concentrations. The $\mathrm{pH}$ was influenced only by limestone.

\section{REFERENCES}

Alleoni LRF, Cambri MA \& Caires EF (2005) Atributos químico de um Latossolo de cerrado sob plantio direto, de acordo com doses e formas de aplicação de calcário. Revista Brasileira de Ciência do Solo, 29:923-934.

Alves AU, Oliveira AP, Alves AU, Dornelas CSM, Alves EU, Cardoso EA, Oliveira ANP \& Cruz IS (2008) Lima beans production and economic revenue as function of organic and mineral fertilization. Horticultura Brasileira, 26:251-254.

Amanullah MM, Alagesan A, Vaiyapuri K, Pazhanivelan S \& Sathyamoorthi K (2006) Intercropping and organic manures on the growth and yield of cassava (Manihot esculenta Crantz). Research Journal of Agriculture and Biological Sciences, 02:183189.

Amanullah MM, Vaiyapuri K, Sathyamoorthi K, Pazhanivelan S \& Alagesan A (2007) Nutrient uptake, tuber yield of cassava (Manihot esculenta Crantz) and soil fertility as influenced by organic manure. Journal of Agronomy, 06:183-187.

Arriaga FJ \& Lowery B (2003) Soil physical properties and crop productivity of an eroded soil amended with cattle manure. Soil Science, 168:888-899.
Bambolim A, Caione G, Souza NF, Seben Junior GF \& Ferbonink GF (2015) Calcário líquido e calcário convencional na correção da acidez do solo. Revista de Agricultura Neotropical, 02:34-38.

Caires EF (2013) Correção da acidez do solo em sistemas plantio direto. Piracicaba, INPI. 13p. (Informações agronômicas, 141).

Camargo OA, Moniz AC, Jorge JA \& Valadares JMAS (2009) Métodos de análise química, mineralógica e física de solos do Instituto Agronômico de Campinas. Campinas, Instituto Agronômico. 77p. (Boletim técnico, 106).

Campos MF, Bicudo SJ \& Ono EO (2004) Influência da calagem e do zinco no desenvolvimento das raízes tuberosas da mandioca. Revista Ceres, 51:597-607.

Embrapa - Empresa Brasileira de Pesquisa Agropecuária (1997) Manual de métodos de análise de solo. $2^{\mathrm{a}}$ ed. Rio de Janeiro, Embrapa. 212p.

Dortzbach D (2009) Dinâmica de atributos físicos e químicos em solo sob plantio direto adubado com dejetos suínos e uréia. Dissertação de Mestrado. Universidade Federal de Santa Catarina, Florianópolis. $127 \mathrm{p}$.

Dos Anjos JL, Sobral LF \& Lima Junior MA (2011) Efeito da calagem em atributos químicos do solo e na produção da laranjeira. Revista Brasileira de Engenharia Agrícola e Ambiental, 15:1138-1142.

Galvão SRS, Salcedo IH \& Oliveira FF (2008) Acumulação de nutrientes em solos arenosos adubados com esterco bovino. Pesquisa Agropecuária Brasileira, 43:99-105.

Hue NV (1991) Effects of organic acids/anions on phosphorus sorption and phytoavailability in soils with different mineralogies. Soil Science, 152:463-471.

IBGE - Instituto Brasileiro de Geografia e Estatística (2017) Sistema IBGE de recuperação automática - SIDRA. Banco de dados Agregados. Available at: https://sidra.ibge.gov.br/tabela/1612\#resultado. Accessed on: March 25 th 2019.

International Potato Center (2010) Facts and figures about sweetpotato. Available at: http:// nkxms1019hx1xmtstxk3k9sko.wpengine.netdna-cdn.com/wpcontent/uploads/PDF/005448.pdf. Accessed on: February 15 2019.

Lorenzi JO (2003) Mandioca. Campinas, CATI. 116 p. (Boletim Técnico, 245)

Magalhães L (2017) Carbono orgânico e atributos físicos do solo após a aplicação de esterco bovino. Dissertação de Mestrado. Universidade Estadual Paulista, Jaboticabal. 23p.

Mathias L \& Kabambe VH (2015) Potential to increase cassava yields though cattle manure and fertilizer application: results from Bunda College, Central Malawi. African Journal of Plant Science, 09:228-234.

Rev. Ceres, Viçosa, v. 67, n.1, p. 023-029, jan/feb, 2020 
Mattos PLP, Gomes JC, Farias ARN \& Fukuda C (2002) Cultivo da mandioca nas regiões Norte e Nordeste do Brasil. In: Cereda MP (Ed.) Agricultura: tuberosas amiláceas latinoamericanas. São Paulo, Fundação Cargill. p.448-504.

Mecabô Júnior J (2013) Influência de uma aplicação de dejeto líquido de suínos sobre atributos do solo e erosão hídrica em um Nitossolo Bruno. Dissertação de Mestrado. Universidade do Estado de Santa Catarina, Lages. 66p.

Menezes RSC \& Silva TO (2008) Mudanças na fertilidade de um Neossolo Regolítico após seis anos de adubação orgânica. Revista Brasileira de Engenharia Agrícola e Ambiental, 12:251257.

Mitchell CC \& Tu S (2006) Nutrient accumulation and movement from poultry litter. Soil Science Society of America Journal, 70:2146-2153

Nassar NMA, Junior OP, Sousa MV \& Ortiz R (2009) Improving carotenoids and amino-acids in cassava. Recent Patents on Food, Nutrition \& Agriculture, 1:32-38.

Natale W (2007) Efeitos da calagem na fertilidade do solo e na nutrição e produtividade da goiabeira. Revista Brasileira de Ciência do Solo, 31:1475-1485.

Odedina JN, Odedina SA \& Ojeniyi SO (2011) Effect of types of manure on growth and yield of cassava (Manihot esculenta Crantz). Researcher, 03:01-08.

Oliveira AP, Reitas Neto PA \& Santos ES (2001) Produtividade do inhame em função de fertilização orgânica e mineral e de épocas de colheita. Horticultura Brasileira, 19:144-147.

Otsubo AA \& Lorenzi JO (2004) Cultivo da mandioca na região Centro-Sul do Brasil. Dourados, Embrapa Agropecuária Oeste. 116p. (Sistemas de produção, 6).

Ourives OEA, Souza GM, Tiritan CS \& Santos DH (2010) Fertilizante orgânico como fonte de fósforo no cultivo inicial de Brachiaria brizantha cv. Marandú. Pesquisa Agropecuária Tropical, 40:126-132.
Pereira GAM, Lemos VT, Santos JB, Ferreira EA, Silva DV, Oliveira MC \& Menezes CWG (2012) Crescimento da mandioca e plantas daninhas em resposta à adubação fosfatada. Revista Ceres, 59:716-722.

Pires AA, Monnerat PH, Marciano CR, Pinho LGR, Zampirolli PD, Rosa RCC \& Muniz RA (2008) Efeito da adubação alternativa do maracujazeiro amarelo nas características químicas e físicas do solo. Revista Brasileira de Ciência do Solo, 32:19972005 .

Primavesi AA (2002) Adubação e nutrição vegetal. In: Primavesi AA (Ed.) Manejo ecológico do solo: agricultura em regiões tropicais. São Paulo, Nobel. p. 258-350.

Rós AB, Narita N \& Hirata ACS (2014) Produtividade de batatadoce e propriedades físicas e químicas de solo em função de adubação orgânica e mineral. Semina: Ciências Agrárias, 35:205214 .

Silva JA, Oliveira AP, Alves GS, Cavalcante LF, Oliveira ANP \& Araújo MAM (2012) Rendimento do inhame adubado com esterco bovino e biofertilizante no solo e na folha. Revista Brasileira de Engenharia Agrícola e Ambiental, 16:253-257.

Silva TO \& Menezes RSC (2007) Adubação orgânica da batata com esterco e/ou Crotalaria juncea. II. Disponibilidade de N, P e K no solo ao longo do ciclo de cultivo. Revista Brasileira de Ciência do Solo, 31:51-61.

Souza LS, Silva J \& Souza LD (2009) Recomendação de calagem e adubação para o cultivo da mandioca. Cruz das Almas, Embrapa. 6p. (Comunicado Técnico, 133).

Ternes M (2002) Fisiologia da planta. In: Cereda MP (Ed.) Agricultura: tuberosas amiláceas latino americanas. São Paulo, Fundação Cargill. p.448-504.

Valle TL (2005) Mandioca: dos índios à agroindústria. Revista Associação Brasileira dos Produtores de Amido de Mandioca, 03:24-25. 